\title{
Properties of Zinc Phosphate Coatings on Carbon Steel Using a Thermostatic Cell and a Mobile System
}

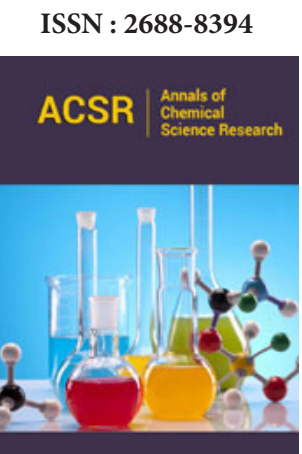

${ }^{* 1}$ Corresponding author: Torres JV, National Institute of Nuclear Research, Mexico

Submission: 想 February 11, 2019

Published: 海 March 12, 2019

Volume 1 - Issue 2

How to cite this article: Reyes A M, Torres J, Barrera G and Díaz C. Properties of Zinc Phosphate Coatings on Carbon Steel Using a Thermostatic Cell and a Mobile System. Ann Chem Sci Res. 1(2). ACSR.000507.2019.

DOI: 10.31031/ACSR.2019.01.000507

Copyright@ Torres JV, This article is distributed under the terms of the Creative Commons Attribution 4.0 International License, which permits unrestricted use and redistribution provided that the original author and source are credited.

\author{
Reyes Astivia JE ${ }^{1}$, Vite Torres J ${ }^{2 *}$, Martínez Barrera $\mathrm{G}^{3}$ and Barrera Díaz $\mathrm{C}^{3}$ \\ ${ }^{1}$ Doctorate in Materials Science of the Faculty of Chemistry, University Autonomous State of \\ Mexico, Mexico \\ ${ }^{2}$ National Institute of Nuclear Research, Mexico \\ ${ }^{3}$ Joint Centre for Research in Sustainable Chemistry UAEM-UNAM, Mexico
}

\section{Introduction}

The effect of corrosion is of concern in the health sector. It can cause disease-corrosion in metals used for implants. The risk of metals being transferred to the environment can cause infections in respiratory diseases. The damage caused at a global level by rust can result in high costs and human loss. It is estimated that 5 tons of steel are dissolved in each second. This phenomenon is invisible in each piece of metal, since it involves a few nano meters or picometers, but when this is multiplied by the quantity of steel used in the world in different areas, the total corrosion is a high value [1]. One of the objectives of this work is to reduce this loss using surface coatings based on the zinc phosphate technique with a mobile device. This work has been carried out using zinc phosphate dipped coatings at room temperature on mild steel at $25{ }^{\circ} \mathrm{C}$ for 30 minutes in the phosphate solution [2], as well as magnesium phosphate on low carbon steel using the electrochemical cathodic immersion method [3]. Phosphate processing with benzotriazole produce a different morphology to other magnesium deposits on carbon steel [4].

Although the surface characterization of zinc coatings on low carbon steel showed that coatings were not hard, but on the other hand they reduced the corrosion and provide a good adhesion for subsequent coatings [5]. There are other types of coatings produced by dipping which have different surface morphologies, such as iron-phosphate coatings on low carbon steel [6]. They are also used to prevent or minimize corrosion and give good adhesion for paints and back coverings.

\section{Methodology}

The chemical composition of the phosphate solution is given in Table 1. The composition of carbon steel samples used for containing is as follows: $0.10 \% \mathrm{C}, 0.60 \% \mathrm{Mn}, 0.030 \% \mathrm{P}$, $0.035 \% \mathrm{~S}$ and the remaining is Fe. The samples were obtained from industrial residues from 3 steel scrapheaps. From each one, 10 samples of were chosen and prepared for coatings. The 
samples were machined to give the geometric forms required for analysis. The surface of the samples was cleaned mechanically. The paint residue was removed by acetone and degreased by ethanol. The composition of zinc phosphate solution was zinc shown in Table 1. The proposed mechanism of the reaction phosphoric acid with the surface of iron was as follows:

Table 1: Chemical composition of the phosphate solution.

\begin{tabular}{|c|c|}
\hline Chemical Name & Concentration $(\mathrm{g} / \mathbf{l})$ \\
\hline Phosphoric Acid $\left(\mathrm{H}_{3} \mathrm{PO}_{4}\right)$ & 40 \\
\hline Zinc Carbonate $\left(\mathrm{ZnCO}_{3}\right)$ & 20 \\
\hline Sodium Fluoride $(\mathrm{NaF})$ & 0.2 \\
\hline Nitro Guanidine $\left(\mathrm{CH}_{4} \mathrm{~N}_{4} \mathrm{O}_{2}\right)$ & 2 \\
\hline
\end{tabular}

$$
\mathrm{Fe}+2 \mathrm{H}_{3} \mathrm{PO}_{4} \leftrightarrows \mathrm{Fe}\left(\mathrm{H}_{2} \mathrm{PO}_{4}\right)_{2}+\mathrm{H}_{2}(1)
$$

A soluble ferrous dihydrogen phosphate was produced, and hydrogen gas was released. Local phosphoric acid depletion occurred at the metal/solution interface. When the primary iron, zinc or manganese phosphates are dissociated in the aqueous solution, the following reactions occur [7]:

$$
\text { Phase 1: } \mathrm{Fe}+2 \mathrm{H}_{3} \mathrm{PO}_{4} \leftrightarrows \mathrm{Fe}\left(\mathrm{H}_{2} \mathrm{PO}_{4}\right)_{2}+\mathrm{H}_{2} \uparrow(1)
$$

Phase 2: where $\mathrm{M}=\mathrm{Zn}, \mathrm{Mn}$ or Fe

$$
3 \mathrm{M}\left(\mathrm{H}_{2} \mathrm{PO}_{4}\right)_{2} \leftrightarrows \mathrm{M}_{3}\left(\mathrm{PO}_{4}\right)_{2}+4 \mathrm{H}_{3} \mathrm{PO}_{4}(2)
$$

Phase 3: $\mathrm{Fe}\left(\mathrm{H}_{2} \mathrm{PO}_{4}\right)_{2} \leftrightarrows \mathrm{FeHPO}_{4}+\mathrm{H}_{3} \mathrm{PO}_{4}(3)$

The overall reaction is

$$
3 \mathrm{M}\left(\mathrm{H}_{2} \mathrm{PO}_{4}\right)_{2}+\mathrm{Fe} \leftrightarrows \mathrm{M}_{3}\left(\mathrm{PO}_{4}\right)_{2}+\mathrm{FeHPO}_{4}+3 \mathrm{H}_{3} \mathrm{PO}_{4}+\mathrm{H}_{2} \uparrow(4)
$$

Neutralization of the phosphoric acid in equation (1) alters the direction of equilibrium in all other equations (2), (3) and (4), so that they have the tendency to produce phosphates which are shown to the right of the chemical reactions and cause the deposition of hydrogen phosphates and insoluble phosphates on the metal surface. As reaction (1) takes place, the phosphating solution that contains zinc or manganese phosphate with little or no dissolved iron, it is clearly observed that the untreated samples produce coatings which always contain ferrous dihydrogen phosphate derived from the steel samples. After prolonged use, a manganese phosphate bath frequently contains more iron in solution than manganese and produces coatings of three or more times iron than manganese. The compounds produced from the reaction of iron (Fe) in the carbon steel samples with the phosphating solution have the following chemical formulas.

$$
\begin{gathered}
\mathrm{Zn}_{2}(\mathrm{Fe})\left(\mathrm{PO}_{4}\right)_{2} \cdot 4 \mathrm{H}_{2} \mathrm{O} \text { (Phosphophyllite) } \\
\mathrm{Mn}_{2} \mathrm{Zn}\left(\mathrm{PO}_{4}\right)_{2} \cdot 4 \mathrm{H}_{2} \mathrm{O} \\
\mathrm{Zn}_{3}\left(\mathrm{PO}_{4}\right)_{2} \cdot 4 \mathrm{H}_{2} \mathrm{O} \text { (Hopeite) }
\end{gathered}
$$

\section{Coating process using a thermostatic cell}

The phosphating process produces a relatively inert film (Passivation) on the surface of a material (often a metal) which prevents the interaction of the external agent and the metal. The chemical reaction is reduced or completely impeded by increasing the adhesion of the paint on the metal surface. This will prevent the corrosion and improve lubrication for forming or drawing processes. It can be also the base for subsequent coatings or paints. The primary coating on the carbon steel surface (1) was deposited by thermostatic immersion cell (2) using a phosphating solution (3). This process gives a primary coating with better paint adhesion. The phosphating solution passes through a latex tube (4) which is connected to the water bath (5) fixed at different temperatures: 20, $30,40,50,60,70$ and $80{ }^{\circ} \mathrm{C}$ by using a regulator (6) that maintain the temperature at the required value as shown in Figure 1.

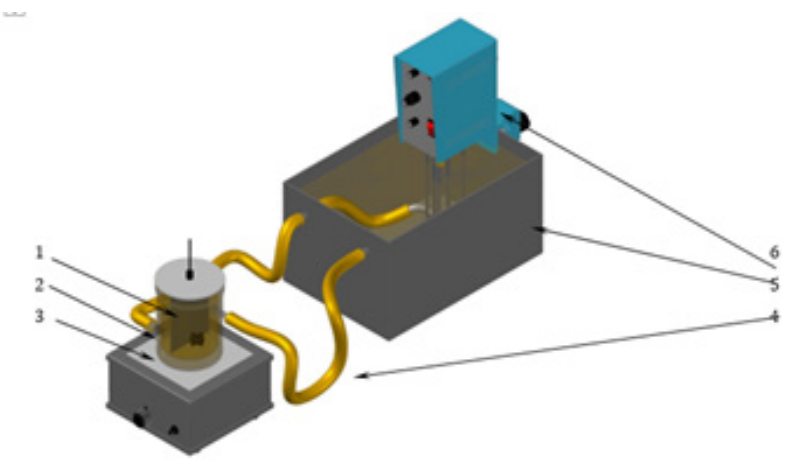

Figure 1: Thermostatic system.

\section{Coating process using a mobile device}

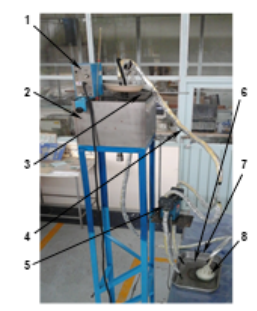

$$
\begin{aligned}
& \text { 1. Water Bath } \\
& \text { 2. Stainless steel container } \\
& \text { 3. Vase of precipitates } \\
& \text { 4. Thermally insulated low pressure } \\
& \text { hoses with fiberglass } \\
& \text { 5. Diaphragm pump } \\
& \text { 6. Substrate } \\
& \text { 7. Stainless steel tray } \\
& \text { 8. Mobile device (nylon) }
\end{aligned}
$$

Figure 2: The structure and the components used for coating by mobile device method.

The structure and components of the process for applying nickel metal coatings by the Watts bath method (Mobile method) was shown in Figure 2. The heating operation was performed approximately one meter above the mobile device [9]. The fluid with the desired temperature was carried out and circulated the electrolyte for deposition on the substratum. When this temperature had been reached, the solution flowed by gravity through an insulated hose towards the body of the mobile device. Then, this solution dispersed on the metal surface by direct contact of the electrolyte solution with the surface of the metal sample. The remaining solution was collected and transferred to a vessel which was immersed in the water bath. The coating solution was returned back to the water bath through an insulated duct using a diaphragm pump, as shown in Figure 2. 
Figure 3 shows the hemispherical main body forming an inner chamber, which was made of nylon. The device had hex nuts which attached to a flexible insulated duct to carry the phosphate solution. At the top of the main body of the device, there was a connector which carried the coating solution from the outlet of the duct to the body of the device. This connector had a perforated lower spherical outlet that dispersed the solution on the surface. Inside the chamber above a perforated circular plate, there were spheres of ceramic material which assist the distribution of the solution within the body of the device to be spread evenly along the entire circular perforated plate. Around this plate, there was a circular nut that has the ability to access to the interior chamber device when cleaning was required $[10,11]$.

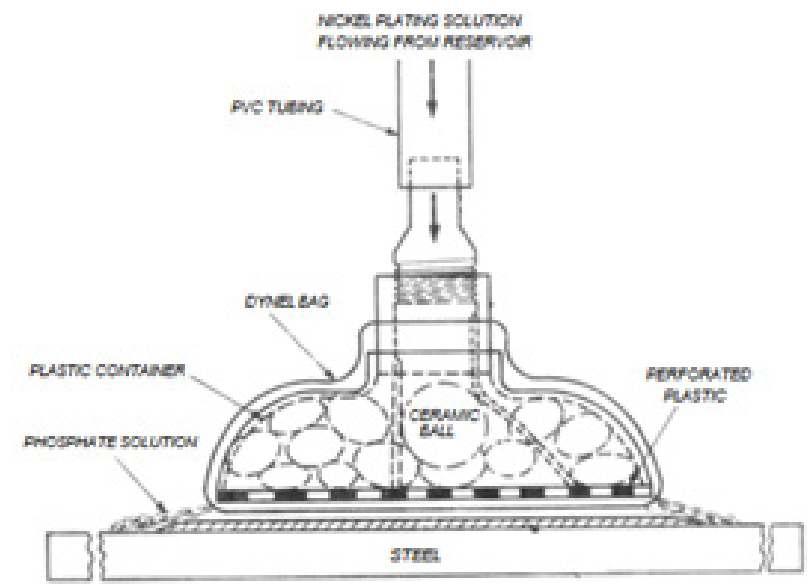

Figure 3: Metal phosphate mobile device.

\section{Results and Discussion}

Results of the phosphating process using the thermostatic cell

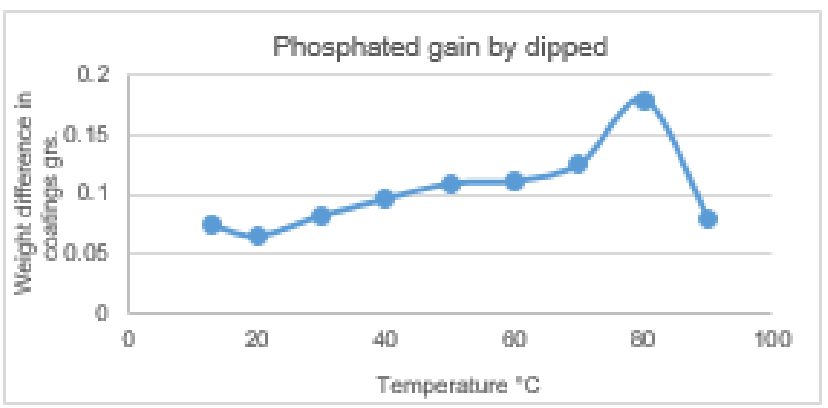

Figure 4: The mass obtained by dipped of zinc phosphate.

Figure 4 shows the weight increase of the samples coated at different temperatures using the thermostatic cell. At all temperatures: $13,20,30 \ldots 80^{\circ} \mathrm{C}$, it was observed that the surface coatings increased the mass of the samples. At $90{ }^{\circ} \mathrm{C}$, the solution started to boil, which means it was no longer possible to coat all the surfaces. The formed bubbles prevented the coating process, so that the metal began to corrode. The optimum temperature for coating the entire surface of the samples was $80{ }^{\circ} \mathrm{C}$. It can be clearly noticed that the content of the phosphate coating increased with the increase in the temperature. This means that the surface of the sample was more and more covered with the phosphate coating until it was became completely covered. The thickness of the obtained layer using the thermostatic cell method was equal to $77 \mu \mathrm{m}$, (Figure 5).

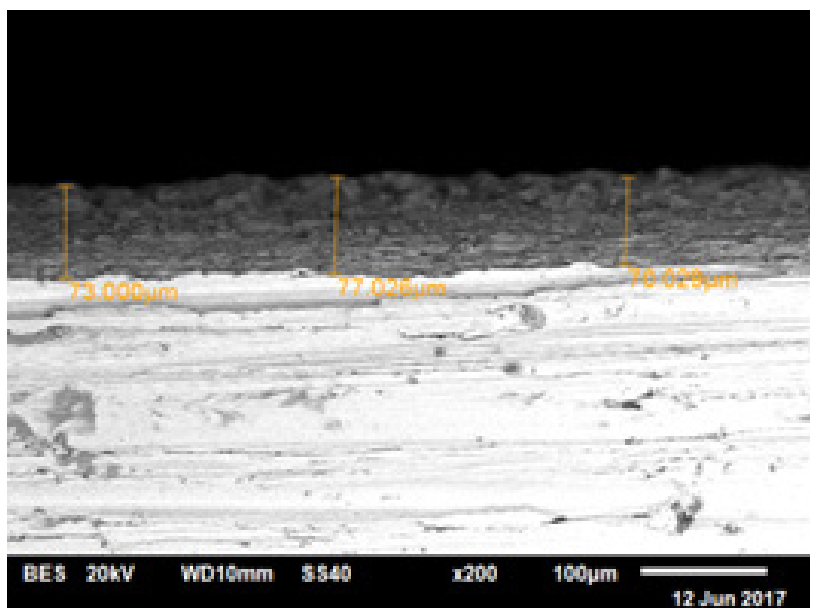

Figure 5: Photomicrograph of the thickness of the layer obtained by the thermostatic cell method.

\section{Scanning electron microscopy}

Table 2: The results obtained for carbon steel dipped in phosphate solution using the thermostatic cell.

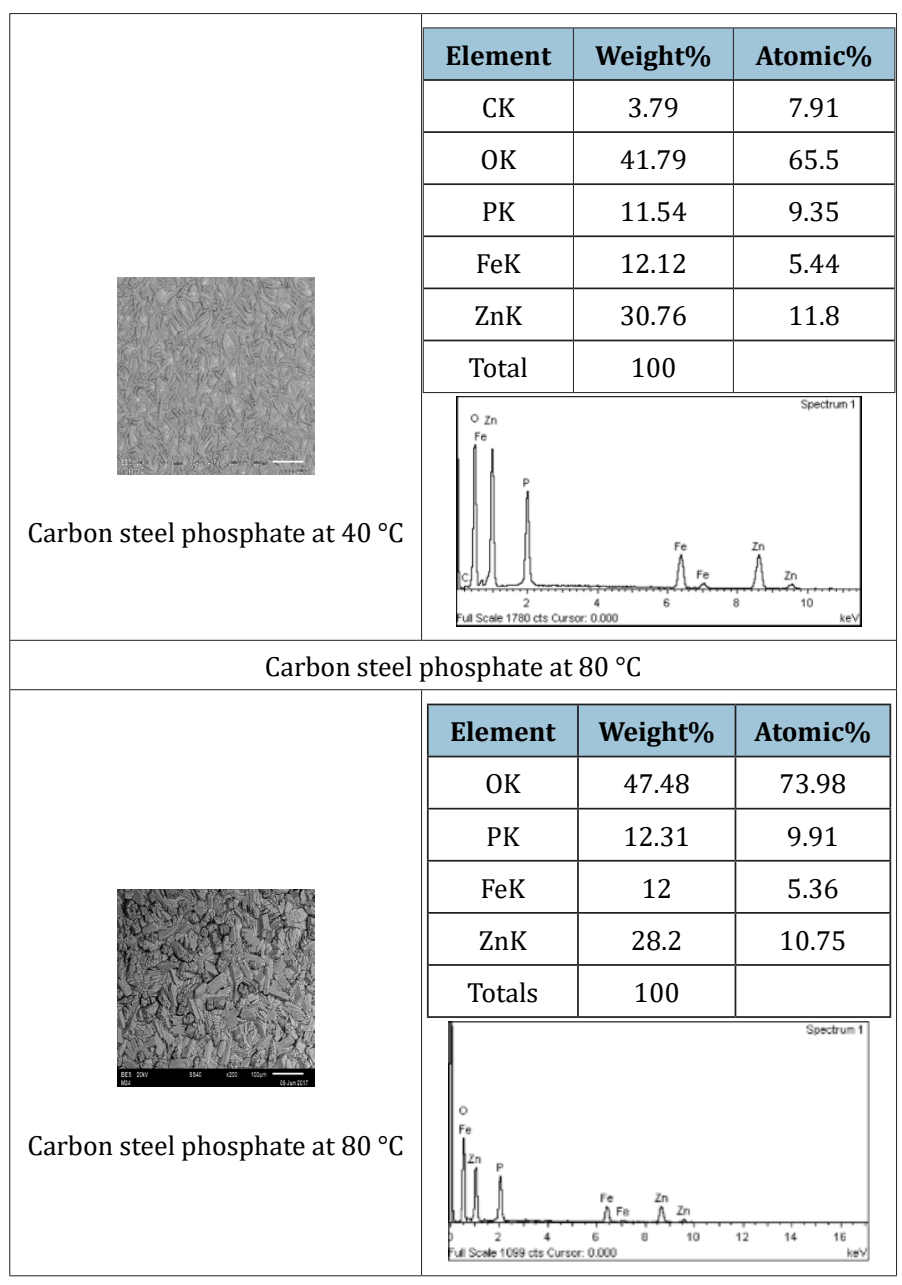


Both scanning electron microscopy (SEM) and x-ray diffraction (XRD) were used to study the morphology and the chemical composition of the phosphating coating on the metallic surface of carbon steel. The coating thickness was about $77 \mu \mathrm{m}$. The SEM analysis was performed on a number of phosphate coatings prepared at different temperatures. The results obtained from the mobile device method at $40{ }^{\circ} \mathrm{C}$ are tabulated in (Table 2). The coatings obtained on the surface, do not contain metal phosphate compounds, compared with the one that was done at $80^{\circ} \mathrm{C}$ (Table 2), The images were enlarged 200 times.

\section{X-ray microscopy}

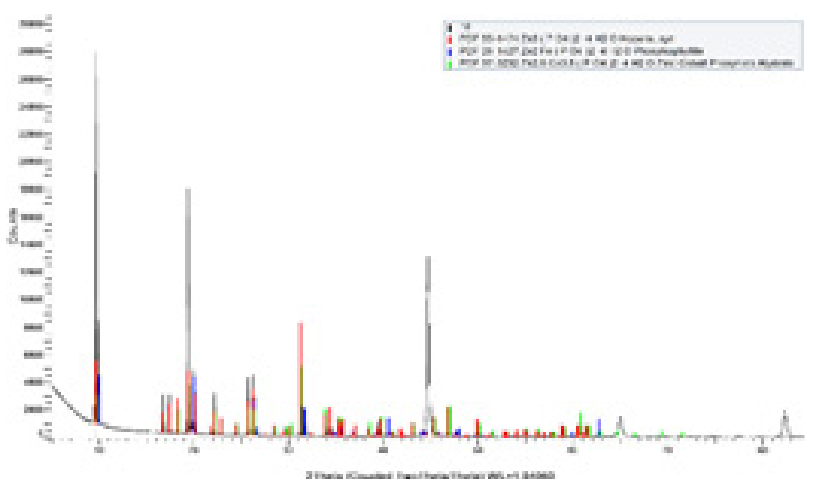

Figure 6: DRX phosphating by immersion at $40^{\circ} \mathrm{C}$.

X-ray analysis showed the diffractograms of phosphate coatings on the surface of carbon steel samples at $40{ }^{\circ} \mathrm{C}$ using the thermostatic cell. The diffractograms were obtained using X-ray diffractometer (DRX-D8 discover Bruker). The coatings of phosphates were found to be mainly of Hopeite $\left(\mathrm{Zn}_{3}\left(\mathrm{PO}_{4}\right)_{2} \cdot 4 \mathrm{H}_{2} \mathrm{O}\right)$ and phosphophyllite $\left(\mathrm{Zn}_{2} \mathrm{Fe}\left(\mathrm{PO}_{4}\right)_{2} \cdot 4 \mathrm{H}_{2} \mathrm{O}\right)$ according to the previous proposed reaction mechanism in Figure 6 \& 7 .

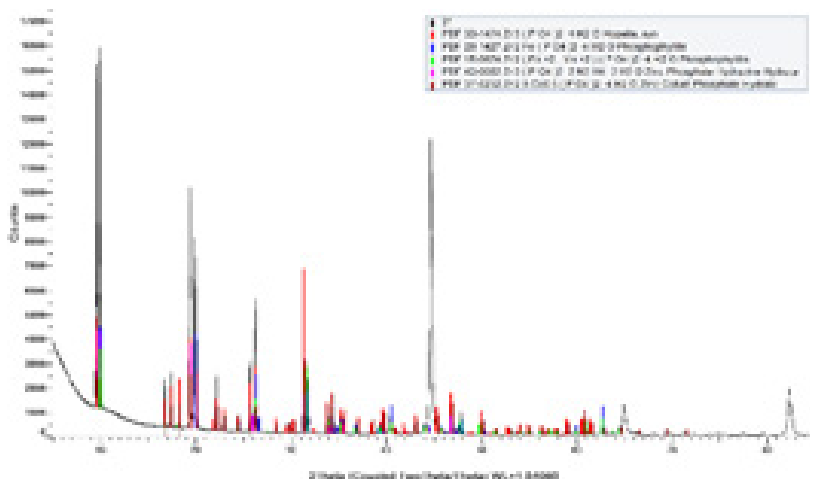

Figure 7: DRX phosphating by immersion at $80{ }^{\circ} \mathrm{C}$.

\section{Results of the mobile device}

Figure 8 shows the weight of the coated studied samples at different temperatures using the mobile phosphating system. It was found the mass of the surface coatings increased with temperature till it reaches $50{ }^{\circ} \mathrm{C}$, then the metal began to corrode. It was found that the optimum coating temperature for the entire surface of the substrate was $40{ }^{\circ} \mathrm{C}$, unlike the dipped process, which had a higher optimum coating temperature $\left(80^{\circ} \mathrm{C}\right)$. Coating at different temperatures was done using this process. The SEM technique shows that $40{ }^{\circ} \mathrm{C}$ was the ideal temperature to coat all the sample surface (Table 3 ).

Table 3: Mass \% of carbon steel phosphate coatings using the mobile device method.

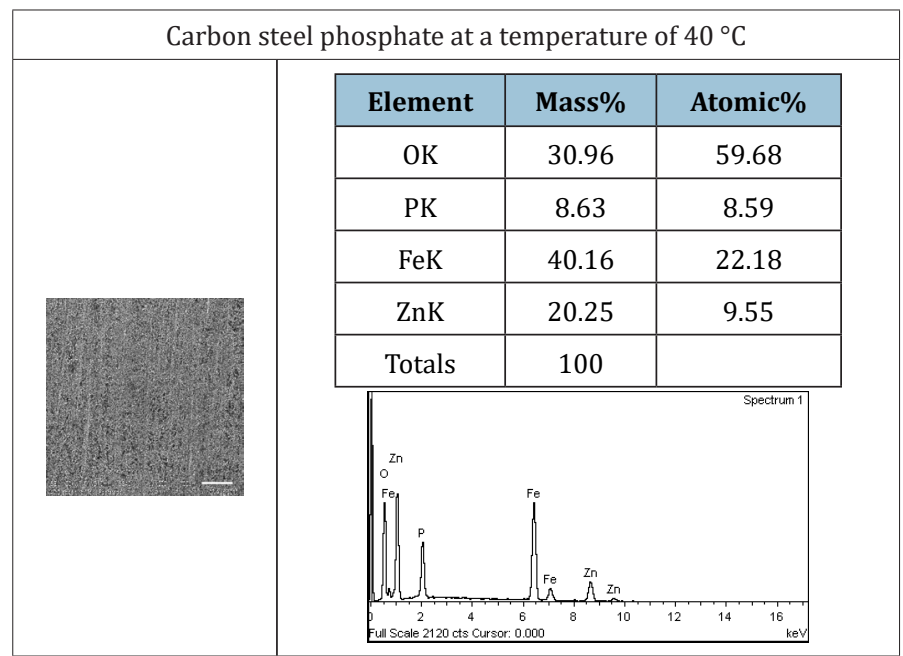

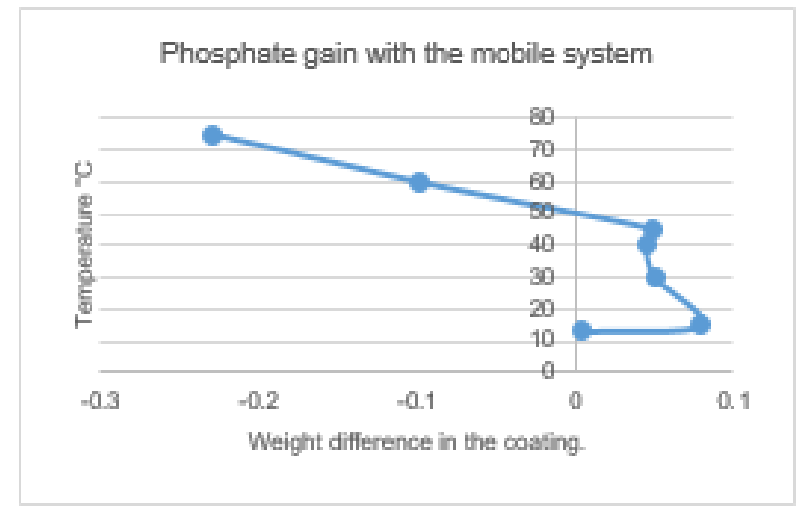

Figure 8: Mass obtained by dipping in zinc phosphate solution.

X-ray microscopy

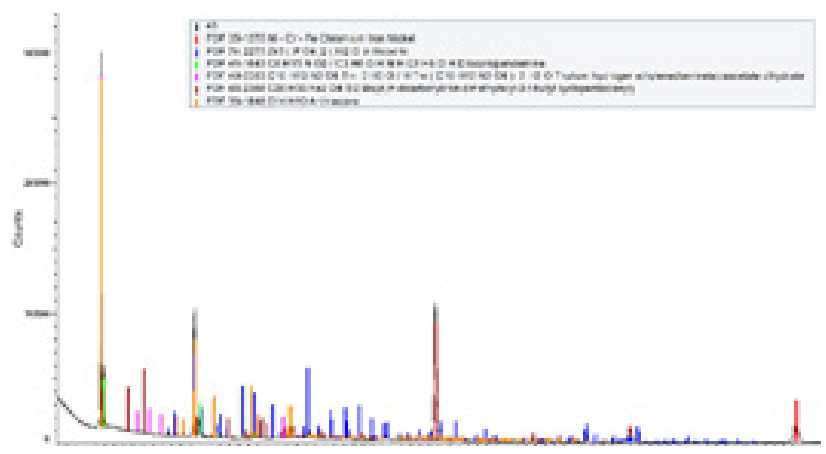

Figure 9: XRD for phosphating coatings of the samples at $40{ }^{\circ} \mathrm{C}$ using the mobile device method.

X-ray analysis were performed on the coatings obtained from phosphating the samples at different temperatures of the carbon steel using the mobile device method (Figure 9). 


\section{Conclusion}

The methodology used for metal surface coatings, using the mobile device method, can be used to do the field work without the need to remove the deteriorated carbon steel components. In this way, the maintenance costs associated with disassemble and transportation of the components, could be reduced. The characteristics of the primary coatings by the immersion methods gave a layer of thickness of $15.1 \mu \mathrm{m}$ at a temperature of $80^{\circ} \mathrm{C}$. The characteristics of the primary coatings by the spray method using the mobile device gave a reaction mechanism similar to immersion, but with thicknesses of $3.6 \mu \mathrm{m}$ at $40^{\circ} \mathrm{C}$. At higher temperatures, the metal substrate underwent accelerated corrosion. Therefore, it is recommended to use a temperature of $40{ }^{\circ} \mathrm{C}$ to obtain an evenly homogeneous with very well adhered coatings on the metal surface.

\section{Acknowledgments}

The authors thank to Consejo Nacional de Ciencia y Tecnología (CONACYT) of México, for the scholarship granted to Jesús Eliseo Reyes Astivia.

\section{References}

1. Ballester JR, Ballester ME, Calatayud ML, Sabater JV, Trilles E (2011) Química 2o Bachillerato publicista, p. 209.

2. Rezaee N, Attar MM, Ramezanzadeh B (2013) Studying corrosión performance, microstructure and adhesion properties of a room temperature zinc phosphate conversion coating containing $\mathrm{Mn}^{2+}$ on mild steel. Surface and Coatings Technology 236: 361-367.
3. Dayyari MR, Amadeh A, Sadreddini S (2015) Application of magnesium phosphate coating on low carbon steel via electrochemical cathodic method and investigación of its corrosión resístanse. Jornal of Alloys and Compounds 647: 956-958.

4. Zuo J, Guo F, Zhu J, Chen A, Hu y, et al. (2015) Effects of benzotriazole on the magnesium phosphate coating. Applied Surface Science 359: 166171.

5. Kumar A, Bhola SK, Majumdar JD (2012) Microstructural characterization and surface properties of zinc phosphated medium carbon low alloy steel. Surface and Coatings Technology 206: 3693-3699.

6. Bryant M, Neville A (2016) Corrosion and mechanical properties. Orthopaedics and Trauma 30(3): 176-191.

7. Lin XJ, Xu X, Zeng X, Xu L, Zeng Z, et al. (2017) Decreased vaccine antibody titers following exposure to multiple metals and metalloids in e-wasteexposed preschool children. Environmental Pollution 220: 354-363.

8. Ali K, Kim RY, Karim R, Mayal JR, Martin KL, et al. (2017) Role of iron in the pathogenesis of respiratory disease. International Journal of Biochemistry and Cell Biology 88: 181-195.

9. Torres JV (2007) Dispositivo móvil termostatizado para recubrir con fosfato de cromo al aluminio. Patente Mexicana No. 245904.

10. Popic JP, Jegdic BV, Bajat JB, Veljovic D, Stevanovic SI, et al. (2011) The effect of deposition temperature on the surface coverage and morphology of iron-phosphate coatings on low carbon steel. Applied Surface Science 257(24): 10855-10862.

11. Lari AN (1986) Advances in surface treatments: Technologyapplications-effects. Ed. Pergamon press, UK, Volume 5. 